The Historical Journal, 64, 5 (2021), pp. 1355-1378 (C) The Author(s), 2021 . Published by Cambridge University Press.. This is an Open Access article, distributed under the terms of the Creative Commons Attribution licence (http://creativecommons.org/licenses/by/4.o/), which permits unrestricted re-use, distribution, and reproduction in any medium, provided the original work is properly cited.

doi:10.1017/Soo 18246 X2000o631

\title{
BRITISH EXPEDITIONARY FORGE VEGETABLE SHOWS, ALLOTMENT CULTURE, AND LIFE BEHIND THE LINES DURING THE GREAT WAR*
}

\author{
ALEX MAYHEW \\ London School of Economics and Political Science
}

A B STRACT. Popular perceptions of I I I 4-I 8 focus on the trenches. Yet, much of soldiers' time was spent in rear areas and many men never reached the frontlines. By studying life behind the lines it is possible to offer new perspectives on the experience of the Great War. In August I9I 7 and I9I8, the British Expeditionary Force (BEF) took over the usually quiet paths and lawns of Le Havre's Jardin St Roche, which the mayor of the town had agreed to loan to the base commandant. Rather than engaging in battle with the enemy, BEF servicemen and Belgian military personnel, alongside French civilians, were displaying the fruits (and vegetables) of their more peaceful labours. As part of a programme encouraging the cultivation of unused land around the surrounding camps, a vegetable competition was organized in which it was onions, beets, and kale rather than bullets, grenades, and shells that were the produce of war. This article explores the ways in which the organization of these events can throw light on the broader history of the British Army during the First World War. In doing so, it provides novel insights into the functioning of the BEF and the experiences of the men serving in it.

Le Havre, a French port city, appears frequently in the annals of English and British history. It was from here that Louis XV planned to stage an invasion of Britain in 1759. Its neighbour, Harfleur, was besieged by Henry V in $14^{1} 5$ at the beginning of what came to be one of England's most famous military

London School of Economics and Political Science, Houghton Street, Holborn, London WC2A 2AE, UK a.c.mayhew@lse.ac.uk

* I owe a debt of gratitude to Dr Ann-Marie Foster who first brought the material here to my attention. I am also grateful to the anonymous reviewers for their comments on the original submission. An earlier version of this article was presented at the conference '1918-2018: the end of the war \& the reshaping of a century' held at the University of Wolverhampton in 2018. I would like to thank the audience for their advice and insights, which were of great benefit once I came to write this article. 
campaigns. ${ }^{1}$ The focus of this article, however, is on events that took place there five hundred years later. Le Havre was transformed by the Great War, albeit temporarily. It became one of the main logistical arteries for the British Expeditionary Force (BEF). No. 1 Base Headquarters were located here and it was a place that, in many soldiers' eyes, became almost British due to its semi-permanent population of people from the United Kingdom. It was not just demographics that changed the character of the city. During the war (and, indeed, after the Armistice in 1919), a peculiar series of events took place there. In August 1917 and 1918, the BEF's soldiers took over the usually quiet paths and lawns of the park at Jardin St Roche, which the mayor had agreed to loan to the British base commandant for a very particular and unusual purpose. Rather than engaging in battle with the enemy, British soldiers and Belgian military personnel, alongside French civilians, were displaying the fruits (and vegetables) of their more peaceful labours. As part of a programme encouraging the cultivation of unused land around the surrounding camps, a vegetable competition was organized in which it was onions, beets, and kale rather than bullets, grenades, and shells that were the key produce of war. This article will explore the ways in which the organization of these events can throw light on the broader history of the British Army and of the First World War. In doing so, it offers new insights into the functioning of the BEF and the experiences of the men who served in it.

Over the last thirty years, the historical perspective on the BEF in $19^{1} 4^{-1} 8$ has been nuanced and transformed. In part, this was a natural by-product of the opening of the archives, which have provided scholars with a richer source base from which to interrogate the events that took place in Belgium and France. ${ }^{2}$ The changing historical Zeitgeist has also pushed historians to open new windows onto the conflict. The power of social and later cultural history approaches have been at the core of this shift towards histories focused on

${ }^{1}$ F. McLynn, I759: the year Britain became master of the world (London, 2005); J. Baker, Agincourt: the king, the campaign, the battle (London, 2005); and J. Keegan, The face of battle: a study of Agincourt, Waterloo, and the Somme (London, 1976). For some informative modern histories of Le Havre, A. Knapp, 'The destruction and liberation of Le Havre in modern memory', War in History, 14 (2007), pp. 476-98; K. Marsh, 'Colonial workers, imperial migrants and surveillance: policing in Le Havre, 1914-1940', Social History, 43 (2018), pp. 1-29. For a more wide-reaching history of the city, E. Saunier and J. Barzman, Histoire du Havre (privately published, 2017).

${ }^{2}$ I. Beckett, T. Bowman, and M. Connelly, The British Army and the First World War (Cambridge, 2017). For historiographical trends in Britain, B. Bond, The unquiet western front: Britain's role in literature and history (Cambridge, 2001). For historiographical trends in First World War studies more generally, H. Jones, 'As the centenary approaches: the regeneration of First World War historiography', Historical Journal, $5^{6}$ (2013), pp. 857-78; A. Kramer, 'Recent historiography of the First World War (Part I)', Journal of Modern European History, 12 (2014), pp. 5-27, and 'Recent historiography of the First World War (Part II)', Journal of Modern European History, 12 (2014), pp. ${ }^{155^{-7}}$. 
the identity and interior worlds of British soldiers. ${ }^{3}$ It is now clear that not only were the home front and western front deeply interconnected, but that the military did not dampen popular culture; in fact, it actively embraced it as a tool for encouraging morale. 4 Amongst the most enduring statements of this is found in the work of J. G. Fuller. Fuller's Troop morale and popular culture sought to expand upon the literature exploring soldiers' morale in 1914-18-which had tended to focus on life in the frontlines - by investigating their life behind the lines, primarily through the lens of soldiers' newspapers, also known as 'trench journals'. Fuller suggested that the culture that civilian soldiers brought with them was well suited to their lives in the army. Football and theatre, as well as rugby and music hall, helped men to relax and maintained their endurance. Interestingly, Fuller suggests that the military originally paid little attention to the entertainment of its men and that it was the soldiers (with the support of their officers) that took it upon themselves to organize games and performances. Later, these became institutionalized and provide an example of an army drawing its energy from the bottom up. 5

Although this article is not a study of morale, it will offer insights that shed light on the endurance of the BEF. In the same vein as Fuller, though, this article is concerned with what events behind the line can tell us about the experience of the conflict. There has been increased scholarly attention paid to the lives of men outside of battle and in rear areas. Popular assumptions that the soldiers spent most or even the majority of their time in waterlogged trenches have been challenged (though with questionable success) as scholars have revealed the diversity of experiences confronting the men of $1914^{-1} 8 .^{6}$

3 T. Ashworth, Trench warfare, I9I4-I9 I 8: the live and let live system (London, 2000; orig. edn 1980); D. Englander, 'Soldiering and identity: reflections on the Great War', War in History, 1 (1994), pp. 300-18; J. Bourke, Dismembering the male: men's bodies, Britain and the Great War (Chicago, IL, 1999); M. Connelly, Steady the Buffs! A regiment, a region, and the Great War (Oxford, 2006); J. Meyer, Men of war: masculinity and the First World War (London, 20o9); M. Roper, The secret battle: emotional survival in the Great War (Manchester, 2oog), and 'Nostalgia as an emotional experience in the Great War', Historical Journal, 54 (2011), pp. $4^{21-51}$; H. McCartney, Citizen soldiers: the Liverpool Territorials in the First World War (Cambridge, 2011).

4 A. Gregory, The last Great War: British society and the First World War (Cambridge, 20o8), esp. pp. 277-83. For broader studies of popular culture during the First World War, see, for example, J. Meyer, ed., British popular culture and the First World War (Leiden and Boston, MA, 2008); and C. Tholas-Disset and A. Ritzenhof, eds., Humor, entertainment, and popular culture during World War I (New York, NY, 2015).

5 J. G. Fuller, Troop morale and popular culture in the British and Dominion armies (Oxford, 1990). For further studies of soldiers' morale in the British Army, G. Sheffield, Leadership in the trenches: officer-man relations, morale and discipline in the era of the First World War (London, 200o); T. Bowman, The Irish regiments in the Great War: discipline and morale (Manchester, 2003); A. Watson, Enduring the Great War: combat, morale, and collapse in the German and British armies, I9I 4-I9I8 (Cambridge, 2008); J. Kitchen, The British Imperial Army in the Middle East: morale and military identity in the Sinai and Palestine campaigns, I9I6-I9I8 (London, 2014).

${ }^{6}$ For statistics on the daily lives of soldiers in 1 st through 4 th Divisions, R. Grayson, 'A life in the trenches? The use of Operation War Diary and crowdsourcing methods to provide an 
Craig Gibson has provided the most comprehensive picture of the BEF's organization in the rear zones, where farming and cultivation took place, and men developed deep and lasting relationships with locals. 7 Many soldiers, outside of the horror of battle, saw the war as an opportunity for exploration and travel; ${ }^{8}$ historians have also highlighted relationships between soldiers and sex workers. ${ }^{9}$ Scholars have also begun to unpick the nature and strength of men's emotional relationship with the physical world they encountered on active service. ${ }^{10}$

Yet, there are still facets of life behind the lines of which little is known. Namely, the allotment culture that became pervasive in the semi-permanent camps that helped sustain the British war effort. Gardening was a popular pastime in Edwardian Britain. ${ }^{11}$ Allotments, too, had become a central feature of working-class life (both rural and urban) by the beginning of the twentieth century. ${ }^{12}$ So significant were they that legislation had been introduced, in the form of the Small Holding and Allotments Act (1907), that stipulated that local authorities were obliged to meet the demand for allotments. ${ }^{13}$ What is more, '[f] ood generally has been identified as a central concern and obsession in soldiers' contemporary letters and diaries and subsequent memoirs'. ${ }^{14}$ Beyond the sustenance good rations provided, Rachel Duffet has

understanding of the British Army's day-to-day life on the western front', British Journal for Military History, 2 (2016), pp. 1-28. For popular myths, G. Sheffield, Forgotten victory: the First World War myths and realities (London, 2001); D. Todman, The Great War: myth and memory (London, 2005).

7 C. Gibson, Behind the lines: British soldiers and French civilians, I9I4-I9I8 (Cambridge, 2014). Also A. Dowdall, 'Civilians in the combat zone: Allied and German evacuation policies at the western front, 1914-1918', First World War Studies, 6 (2015), pp. 239-55.

8 A. Mayhew, 'A war imagined: postcards and the maintenance of long distance relationships during the Great War', War in History, Online First 7 Nov. 2019 (https://doi.org/10.1177/ og68344519831039, accessed 21 July 2020).

9 S. Grayzel, 'Mothers, marraines, and prostitutes: morale and morality in First World War France', International History Review, 19 (1997), pp. 66-82; Bourke, Dismembering the male, pp. $155^{-6}$; C. Gibson, 'Sex and soldiering in France and Flanders: the British Expeditionary Force along the western front, 1914-1919', International History Review, 23 (2001), pp. 53979; C. Makepeace, 'Male heterosexuality and prostitution during the Great War: British soldiers' encounters with maisons tolérées', Cultural and Social History, 9 (2012), pp. 65-83.

${ }^{10}$ R. J. Wilson, Landscapes on the western front: materiality and the First World War (Abingdon, 2012); and C. Ward, Living on the western front: annals and stories, I9I4-1919 (London, 2013). See also S. Das, Touch and intimacy in First World War literature (Cambridge, 2005).

${ }^{11} \mathrm{~J}$. Kay, "No time for recreations till the vote is won"? Suffrage activists and leisure in Edwardian Britain', Women's History Review, 16 (2007), pp. 540-2; A. Halmreich, The English garden and national identity: the competing styles of garden design, I870-I9I4 (Cambridge, 2002).

${ }_{12}$ D. Crouch and C. Ward, The allotment: its landscape and culture (Nottingham, 1994).

13 R. J. Wilson, 'Cultivating the city and its citizens: the creation of corporate allotments in York', International Journal of Regional and Local Studies, 6 (2010), pp. 8-57, and 'Social reform and allotment gardening in twentieth-century York', Journal of Urban History, $3^{8}$ (2012), pp. 731-52. See also P. Readman, 'The Edwardian land question', in M. Cragoe and P. Readman, eds., The land question in Britain, I750-1950 (London, 2010), pp. 181-200.

${ }^{14}$ Beckett, Bowman, and Connolly, The British Army and the First World War, p. 15 o. 
shown how central food could be the social and cultural life of British soldiers. She also pointed to the existence of gardens in rear areas, though did not study them in much detail. ${ }^{15}$ Duffet suggests that men were unwilling to invest their time in these whilst 'at rest', but soldiers' penchant for gardening has been highlighted elsewhere. ${ }^{16}$ As yet, however, there has been no real attempt to knit these insights together with the BEF's vegetable shows at Le Havre, nor its allotment culture, into a 'Fuller-esque' history of the BEF.

This article will do exactly that by using a series of documents collected by the staff of No. 1 Base, Le Havre, which were later sent to the British Museum. They are now held by the British Library and sit in a red booklet containing other artefacts of 1914-18: ration books; programmes from concerts, plays, and sports meets; a pamphlet from a GHQ debating society; and Christmas day menus. ${ }^{17}$ Ann-Marie Foster, in a short article on the ephemera held by the British Library, has noted that the 'research potential of these documents is, as yet, untapped'. ${ }^{18}$ Unlike much of this particular collection, the papers related to the vegetable shows that took place at Le Havre in 1917 and 1918 present a relatively complete narrative. The first sections of this paper focus on Le Havre and the competitions that took place there. Yet, to delve deeper into this history, it then widens its lens by studying a soldiers' newspaper produced by servicemen keeping allotments elsewhere on the western front. In doing so, it provides new perspectives on the experiences of soldiers during the Great War. While this is not a conventional 'microhistory', the focus on the theme of allotments and these vegetable shows does allow this article to 'search for answers to large questions in [relatively] small places'. ${ }^{19}$ By studying the allotment culture and competitions at Le Havre, one can learn more about

${ }_{15}$ R. Duffet, 'A war unimagined: food and the rank and file solider of the First World War', in Meyer, ed., British popular culture and the First World War, R. Duffet, The stomach for fighting: food and the soldiers of the First World War (Manchester, 2012), pp. 124-5. Also J. Hartley, Bully beef Eテ biscuits: food in the Great War (Barnsley, 2015).

16 Watson, Enduring the Great War, p. 24.

17 British Library (BL) Tab.1 1 748.aa.4.1-1 22: First World War, Misc. Leaflets, Programmes. See also 'Vegetable show certificate' (www.bl.uk/collection-items/havre-vegetable-show, accessed 20 July 2020). Some winners' medals can also be found in the Imperial War Museum (IWM) and National Army Museum (NAM), see IWM EPH 3351: vegetable show medals; NAM 1982-o9-84-1: 'Prize medal awarded at the British Expeditionary Force vegetable show at Le Havre, 191'.

18 A.-M. Foster, "I am sending herewith" - First World War ephemera at the British Library', British Library Journal, Article 3 (2017), p. 8. Also A.-M. Foster, 'Mud, blood, and vegetables', Untold lives blog (https://blogs.bl.uk/untoldlives/2016/o8/mud-blood-and-vegetables.html, accessed 18 Nov. 2020).

19 C. W. Joyner, Shared traditions: southern history and folklore (Urbana, IL, 1999), p. 1. For microhistory, see esp. C. Ginzburg, The cheese and the worms: the cosmos of a sixteenth-century miller, trans. John and Anne Tedeschi (Baltimore, MD, 1980), and 'Microhistory: two or three things that I know about it', trans. J. Tedeschi and A. C. Tedeschi, Critical Inquiry, 20 (1993), pp. 10-35. Also S. Gylfi Magnusson, 'The singularization of history: social history and microhistory within the postmodern state of knowledge', Journal of Social History, 36 (2003), pp. $701-35$. 
the organization and administration of the BEF, its relationship with its allies, and the nature of soldiers' lives out of the frontlines. Ultimately, this analysis offers further evidence of the myriad ways in which civilian culture percolated and became fundamental to the British military in $1914^{-18}$.

For obvious reasons, allotments were not a common sight in the frontlines. Yet, in the expansive base camps that sprung up in the rear areas of British operations, they became a common feature of daily life. This was particularly the case in the ports and settlements along the English Channel, which had housed BEF personnel from the earliest days of the war. ${ }^{20}$ British troops streamed through these places on their way to the frontlines. Le Havre's sea and railway connections meant it quickly grew into one of the primary British bases on the continent. Apart from a brief period in 1914, when the German advance had threatened to over-run this part of France, the BEF was a constant feature of city life until 1919. No. 1 Base Headquarters were established at Quai Transatlantique, while other headquarters, directorships, services, and supply depots occupied a variety of other buildings. Around the city itself, a network of new tented settlements was constructed. ${ }^{21}$

Le Havre was many Tommies' first sight of France or of any foreign country for that matter. ${ }^{22}$ The first men arriving in August 1914 were met by crowds of civilians, which underlined the 'foreignness' of the country. ${ }^{23}$ The city, however, became remarkably 'English'. Already, in 1914, the majority of people R. D. Sheffield encountered were from the United Kingdom. ${ }^{24}$ Places such as this very quickly became semi-permanent centres of army logistics. Thousands of soldiers were based and billeted here. ${ }^{25}$ In late 1914, one soldier had already come to consider these ports in the same breath as England and 'Hyde Park'. ${ }^{26}$ A post-war soldiers' travel guide describing Boulogne could just have easily been written for veterans visiting Le Havre. It

became practically an English city; that is to say, a very large proportion of its inhabitants were British. There were huge rest camps for troops going on leave and

${ }^{20}$ A. Fletcher, Life, death and growing up on the western front (Cambridge, MA, 2013), pp. 59-61; Gibson, Behind the lines, p. 3 o.

${ }^{21}$ The National Archive (TNA) WO 95/4030-1: lines of communication, Havre base: commandant, $1914^{-18}$.

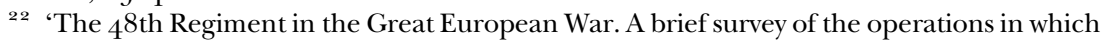
the regiment was engaged', Talavera Magazine, 1 (1 Jan. 1920), p. 3.

${ }^{23}$ IWM Con Shelf: extract from local paper regarding the experience of Pte J. T. Greenwood, Oxfordshire and Buckinghamshire Light Infantry, published 24 Oct. 1914.

${ }^{24}$ IWM 67/239/1: R. D. Sheffield, letter to father, 9 Nov. 1914.

${ }^{25}$ IWM misc. 108 item 1710 : pocket diary 1914, Aug.-Sept. 1914; Soldiers of Oxfordshire Museum (SOFO) box 16 item 42: F. W. Child, diary, 19 Nov. 1916.

${ }^{26}$ IWM misc. 30 item $55^{\mathrm{o}}$ : diary of an unidentified soldier of the [2nd Battalion] Border Regiment, 25 Dec. 1914 . 
returning from leave, situated near the harbour; hospitals sprang up in every direction, and were perpetually full of wounded soldiers; thousands of officers and clerks were employed upon the duties connected with a huge base. ${ }^{27}$

In late 1916, R. E. P. Stevens felt '[one] cannot realise we have arrived in another country everything seems so English'. He found that he was 'only reminded the place was a French port by the names on the shops'. He even found that the women were familiar. Many of them were British and served in units such as the Voluntary Aid Detachments (VADs) or, later, the Women's Army Auxiliary Corps (WAAC). ${ }^{28}$ M. F. Gower reported that

Havre is quite a decent town with its gay shops and cafes, shady avenues of trees, gardens and squares and is quite lively especially after 6 p.m. when the cafes are open to British troops. It is very pleasant sitting in the latter sipping harmless beer, the only drawback are the number of beggars who come in and sing horrible songs thro' their noses. ${ }^{29}$

By 1918 , this hive of activity also reflected the war's international character. The sight of large contingents of 'Chinese and Black men', alongside the cafés, reminded $\mathrm{H}$. T. Madders that he was no longer in Herefordshire. $3^{\circ}$

One trench journal explained that 'quite a town' had appeared in the surrounding countryside. New roads wound their way through a warren of different units and establishments. There were church tents and a wide array of different trades: carpenters, tailors, shipwrights, coopers, and bakers, amongst a vast array of other 'support troops'.$^{1}$ This increasingly complex network of British camps was the entry point to what Chris Ward called (in an otherwise overstated characterization) the 'colony' of 'Befland'. ${ }^{2}$ The rest camps, hospitals, training areas, and other sections of the British military became semipermanent fixtures. Luckily for the soldiers billeted at Le Havre, the wooded hills and valleys offered a pleasant vista (particularly for those who had come from the trenches).33 For most, their experience of Le Havre was transient, with units and drafts continuously coming and going. However, men spent

27 Lt. Col. T. A. Lowe, The western battlefields: a guide to the British line (London, 1920), p. 6. See also E. Stanley, 'No. 59', The Trumpeter: The Organ of the Active Service Army Schools for Havre Area, 1 ( 7 Feb. 1919), p. 4 .

${ }_{28}$ IWM 02/43/1: R. E. P. Stevens, diary 2, 6, and 12 Nov. 1916. See J. K. Watson, 'Khaki girls, VADs, and Tommy's sisters: gender and class in First World War Britain', International History Review, 19 (1997), pp. 32-51, and Fighting different wars: experience, memory, and the First World War in Britain (Cambridge, 2004), esp. chs. 1-3.

29 IWM 88/25/2: papers of M. F. Gower, letter to Flo, 26 June 1917.

$3^{\circ}$ IWM o1/21/1: H. T. Madders, diary 29 Mar. 1918; Wilson, Landscapes on the western front, p. 92; X. Guoqi, Strangers on the western front: Chinese workers in the Great War (Cambridge, MA, $2011)$.

$3^{1}$ 'Extract from "Le Havre" March 25 th A.D. 2015', The Hanger Herald, 7 ( 1 Apr. 1915), pp. $1-2$.

$3^{2}$ Ward, Living on the western front, pp. 18-19, 95-8, 204.

33 IWM 77/107/1: T. G. Rogers MC, diary, 21 Oct. 1915 . 
relatively long periods of time resting, training, or recuperating from injuries here. Some embraced the opportunity to satiate their more carnal desires. 34 A. L. Collis spent the first half of December 1916 in Le Havre; while C. T. O'Neill was camped there for most of January 1918 and found it 'quaint and dirty'.35 There were also a number of units - such as schools, rest depots, and the Army Printing \& Stationery Service - that were posted here permanently. By 1917, the base was a sprawling web of camps, hospitals, prisons, prisoner of war (POW) camps, and administrative offices and between these were allotment gardens built and maintained by soldiers.

Jay Winter and Antoine Prost have argued that such places had

a society with its own distinct rules and associational life, quite distinct from those of the French and Germans...The same social divisions existed, with the public-school ethos in evidence on the one side, and the elaborate schemes built up to occupy the men out of the lines drawing on popular practices of entertainment and leisure. $3^{6}$

Within the port and camps, there were a large selection of activities to divert the soldiers' attention. The opportunity to explore Le Havre as a tourist - visiting its churches and historic buildings - was welcomed, as were the vices on offer, such as women and hard liquor. 37 The camps themselves were not lacking in amusement. 'There is', M. F. Gower told his sister, 'plenty of entertainment in the camp, cinemas, concerts, billiards, library, etc. and we are not overworked by any means'. Le Havre's coastal location also allowed servicemen to indulge in 'sea bathing' and momentarily to forget the war. $3^{8}$ The well-studied sports and theatrical activities common to nearly every part of the line were also found here with plenty of football, rugby, and athletic games, theatre and music hall shows, and concerts taking place.39 For those missing high-quality football, the Royal Garrison Artillery Depot even had a group of talented professional footballers who played charity games. $4^{\circ}$ More uniquely, the gardens that became so pervasive at Le Havre encouraged the camp commandant to hold a vegetable show in the city's Jardin St Roche in August of 1917 and 1918.41

34 IWM 75/25/1: Col. L. H. M. Westropp, memoir, p. 61.

35 IWM 13/8/1: A. L. Collis, diary, 18 Dec. 1916-1 Jan. 1917 ; SOFO box 16 item 30 3/4/ J3/9: Lt. C. T. O’Neill, diary, 1-25 Jan. 1918.

${ }^{36} \mathrm{~J}$. Winter and A. Prost, The Great War in history: debates and controversies, I9 44 to the present (Cambridge, 2005), p. 93.

37 H. Yeandle, 'Lines on L'Église de Notre Dame, Le Havre', Workshops Review: An Active Service Literary Magazine, Produced by A.O.D. Artificers, Le Havre (1 Dec. 1916), p. 8; IWM PP/ MCR/54: Lt. Col. F. C. O'Rorke: diary, 14, 23, and 28 Aug. 1914.

$3^{8}$ 'The last months: a medley', A train errant: being the experiences of a voluntary unit in France and an anthology from their magazine (Hertford, 1919), p. 273; IWM 95/31/1: papers of Miss A. B. Woodroffe, letter to mother, 11 Aug. 1918.

39 Fuller, Troop morale, pp. $7^{2-1} 33$.

$4^{\circ}$ BL Tab.1 1748 .aa.4.65-6.

$4^{1}$ BL Tab.1 1748. aa.4.90-113. 
The vegetable competitions of 1917 and 1918 reflect the fusing of popular and military culture. Gardens were not a new thing in these base camps; nor were they limited only to Le Havre. Boulogne's Convalescent Camp, for example, had extensive vegetable plots at least a year before these shows. $4^{2}$ Craig Gibson has suggested that in 1916 [there was] the realization that the BEF needed to be more proactive in regards to agriculture, especially in the production of vegetables, cereals and forage'.43 Around 1,200 acres of vegetable gardens were established in the Somme area alone. These were, though, cared for by locals who had returned to the area. 44 It is less clear whether cultivation of soldiers' allotments was originally institutionally encouraged or if, excusing the pun, they arose more organically. This was the case with, say, trench names, which were later institutionalized. 45

Civilian culture provided a useful tool to military commanders. The use of civilian experts in military innovation and learning is evident elsewhere. $4^{6}$ Such approaches and activities were not out of character in an institution whose culture was already steeped in the amateur tradition of Britain's public schools. 47 Yet, there is evidence to suggest that such green fingered expressions of civilian culture were often instinctive. Men would, for instance, spend time tending to the flowers in cemeteries and units were keen to beautify the places where their comrades were interred. $4^{8}$ Understandably, gardening offered a period of peace while the cultivation of a plant from seed might have provided men with the semblance of agency in an otherwise chaotic world. In fact, modern research has highlighted just how beneficial gardening is for mental health - it is an effective escape mechanism and strategy for coping with stress. 49 Significantly, one soldiers' journal recorded:

$4^{2}$ IWM Q29187: vegetable garden, No. 1 Convalescent Camp, Boulogne, 6 Oct. 1916.

43 Gibson, Behind the front, p. 207.

44 Ibid.

45 P. Chasseaud, Rats Alley: trench names of the western front, I9I4-1918 (Stroud, 2017; orig. edn 2006).

$4^{6}$ A. Fox, Learning to fight: military innovation and change in the British Army, I9I4-1918 (Cambridge, 2017).

47 P. Parker, The old lie: the Great War and the public-school ethos (London, 2007; orig. edn 1987), pp. 31-2, 37, 77, 96; R. H. Sinnreich, 'An army apart: the influence of culture on the Victorian British Army', in P. Mansoor and W. Murray, eds., The culture of military organizations (Cambridge, 2019), pp. 170-2.

$4^{8}$ A. Mayhew, 'Making sense of the western front: English infantrymen's morale and perception of crisis during the Great War' (Ph.D. thesis, London School of Economics, 2018), p. 78.

49 A. E. Van Den Berg and M. H. G. Custers, 'Gardening promotes neuroendocrine and affective restoration from stress', Journal of Health Psychology, 16 (2011), pp. 3-1 1; C. Genter, A. Roberts, J. Richardson, and M. Sheaff, 'The contribution of allotment gardening to health and wellbeing: a systematic review of the literature', British Journal of Occupational Therapy, 78 $(2015)$, pp. 593-605. 
When men have been teaching Recreational Training weeks on end, it is of no use asking them to play games during their leisure moments. Rest is merely change of occupation, and in a garden the teacher of games will find a chance of employment which will prove both profitable \& recuperative. So that gardening is simply a rest cure. $5^{\circ}$

In 1917 , these allotments were widespread enough to make a large-scale vegetable show practical. It seems that these gardens were first established by individual units and were later embraced by senior leadership for their own ends. Not every unit appears to have developed allotments, and so the base commandant, Brigadier General Nicholson, was interested in encouraging the cultivation of 'all vacant land for the production of vegetables' and the show was an ideal way to do so. $5^{1}$ It also provided an opportunity to nurture a sense of corporate identity within the different camps around Le Havre and the auxiliary units based there: 'all Units having gardens will be invited to exhibit samples of their produce' $.5^{2}$ Tellingly, the show was linked explicitly to the aims of military training, at least its 'moral' dimensions that sought to develop men's character.53 It was hoped that the initiative and prospect of competition would help develop the 'right spirit' amongst men permanently or temporarily posted to the base. Afterwards, officers felt that it had been a success and men had 'shown' this spirit by devoting their 'spare time' to the enterprise and had been 'usefully employed'.54

A vegetable show was a natural choice. In Edwardian Britain, gardening and farming were key dimensions of popular culture and of a national identity that drew heavily (but not solely) on pastoral scenes.55 It would have also appealed to the Victorian and Edwardian tradition of competitive sports, which had already been embraced by the regular army in the decades preceding the Great War. $5^{6}$ However, it was not an easy decision to implement and the event took months to organize. Unlike sports competitions and shows - both of which took place on long-established pitches and in the ubiquitous temporary theatres - this required new logistical apparatus. Memos began circulating in May 1917, some three months before the event, explaining the intention of the

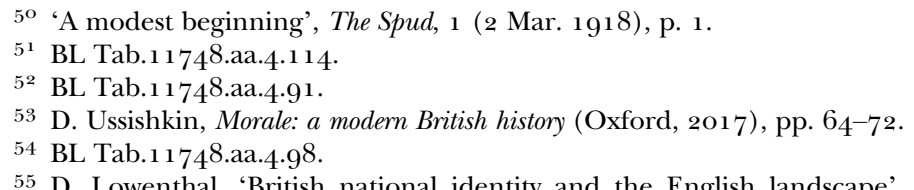

55 D. Lowenthal, 'British national identity and the English landscape', Rural History, 2 (1991), pp. 205-30; P. Readman, "The cliffs are not cliffs": the cliffs of Dover and national identities in Britain, c. $175^{\circ}-$ c. 1950', History: The Journal of the Historical Association, 99 (2014), pp. 241-69, and Storied ground: landscape and the shaping of English national identity (Cambridge, 2018). More generally, too, N. Wouters and L. van Ypersele, eds., Nations, identities and the First World War (London, 2018).

$5^{6}$ See, for instance, P. F. McDevitt, 'May the best man win': sport, masculinity, and nationalism in Great Britain and the empire, I880-I935 (London, 2004); T. Mason and E. Riedi, Sport and the military: the British armed forces, I880-1960 (Cambridge, 2010), esp. chs. 1-3. 
base commandant and asking for suggestions from units. 57 The show itself was a conscious effort to show appreciation for work that had been taking place in the cultivation of land throughout the Le Havre district. There was a desire to ensure that this good work continued and it was intended that the overall productivity of gardens would also be judged. The base commandant also seems to have seen this as an opportunity to nurture relations with Britain's allies; so it was suggested that 'a few classes will be given for French competitors, and perhaps one for Belgium [sic] Military'. $5^{8}$ There was an official search for men 'with an interest or experience' in similar competitions, and units appointed a chief gardener and a competition committee. Importantly, these roles might have offered a legitimate avenue away from the more overbearing demands of military service. 59

The rules of the competition, which were published in June, drew on pre-war models for vegetable shows but were produced in a distinctly military manner. The eleven point framework was strictly hierarchical (judges, who were also senior officers, held absolute authority). It was also published in the same font, coloured ink, and on identical paper to orders of the day. ${ }^{60}$ Furthermore, the suggestion that units took part might well be read as an order: 'The Base Commandant trusts that all those having Gardens will endeavour to enter for one or more Classes, and that every effort will be made to make the Show a success. ${ }^{61}$ Aside from the classes set aside for the Belgian military and French civil population, the remaining categories were open 'to all Camps and Units in the Havre Administrative area' so long as the exhibit was 'bona-fide grown by the Exhibitor'. To avoid disqualification, exhibitors had to present the specified number of vegetables free of dirt, to be submitted the day before the event. All submissions were later donated to local military hospitals. Those soldiers with vegetables, flowers, or fruit 'not provided for in the Schedule of Classes' were also 'cordially invited to send in specimens "FOR EXHIBITION ONLY", 62

The classes included a variety of fruits and vegetables with a focus on quantity and size. The broadest classes were for 'The Best Garden of All'; 'Most Intensive Garden'; 'Best Garden in HARfleur valley'; and 'Collection of Vegetables'. There were then individual categories for potatoes; cabbages; kale; carrots; turnips; swedes; onions; leeks; parsnips; lettuces; radishes; pumpkins; Brussel sprouts; beans (French, runner, and broad); marrows; 'eschalots' or shallots; peas; cauliflowers; celery; tomatoes; and beetroot. There were five categories for French civilians (including one for local students) from Le Havre and the

57 BL Tab. 11748. aa.4.91.

$5^{8}$ BL Tab.1 $1748 . a a .4 \cdot 90$ and BL Tab.1 $1748 . a a \cdot 4 \cdot 91$.

59 BL Tab.11748.aa.4.111.

6o BL Tab.1 1748 .aa.4.90 and BL Tab.1 $1748 . a a .4 .110$.

61 BL Tab. 11748 .aa.4.94.

62 BL Tab. 11748 .aa.4.90. 
call for submissions was advertised in the local newspaper in June. ${ }^{63}$ Additionally, three categories were set aside for the Belgian military present in the area (infantry, artillery, and 'mutiles de la guerre'). ${ }^{6}$ This was indicative of the drive to build bonds between allies, while the decision to compete in separate categories might indicate a desire to avoid competition.

The shows were conceived and planned to fit the mould of any pre-war vegetable competition in Britain. Even here, though, there were a variety of motifs that foregrounded the war. The medals, awarded as prizes to winners, were arguably more reminiscent of a peacetime event than one co-ordinated by a military organization. However, as medals, they would sit nicely alongside the awards that soldiers or units had received in their more militaristic pursuits. First prize (for very highly commended submissions), second prize (the highly commended category), and third prize (simply commended) were all accompanied by detailed medals engraved with the BEF, a crown, a rising sun, and a crop field. These were plated gold, silver, or bronze medallions, but all competitors were given a certificate for taking part. The 1917 entrance form was emblazoned with the British crown and framed by Union and French flags. A detailed stencil depicted some of the vegetables and legumes that might be found at the show. By 1918, the form had become even more detailed, with fauna now depicted alongside vegetables, perhaps reflecting the inclusion of new categories and classes. The competitors' details were framed by flowers and draped flags. It was made clear that this was the BEF's competition, but as well as the British crown, Le Havre's coat of arms was emblazoned at the bottom of the document. ${ }^{6}$

The committee, which commissioned these certificates, was elected by the units and camps around Le Havre and organized the event alongside their military responsibilities. ${ }^{66}$ It was not only these men, though, for whom the event provided a welcome diversion from their usual routine. In a letter to the director of the British Museum, Captain P. H. Browne (the staff captain responsible for the event) explained that the certificate had been 'engraved on stone by a man at this base who in civil life is a clerk in a Gas Company'. This was an impressive piece of artistry. The stencils and headings on the band programmes were similarly 'engraved by an amateur Corporal in the Army Printing \& Stationery Service'.67

The event took place between 14 and 16 August in both 1917 and 1918 and judging occurred on the first day. The gates opened at 8 a.m. and the participants had nearly three hours to arrange their exhibits. They provided their own dishes and plates and were warned 'to remove any debris or mess' and

63 BL Tab.1 1748 .aa.4.10o.

64 BL Tab.1 1748 .aa.4.90 and BL Tab.11748.aa.4.92.

65 BL Tab.1 1748 .aa.4.89 and BL Tab.1 1748.aa.4.9o.

66 BL Tab. 11748. aa.4.99.

67 BL Tab.1 $1748 . a a \cdot 4 \cdot 97$. 
'avoid touching any other exhibits' or risked being disqualified. ${ }^{68}$ Senior officers from across the army were invited to attend, but it was open to everyone. On 14 August, the entrance fee was set at 1 franc, but up to three gardeners from each unit were granted a 'Gardeners' Pass' by their commanding officer. ${ }^{69}$ The gates were opened to invited and paying guests in the afternoon. Later, there were drinks and light refreshments, which were accompanied by music played by the band of the 2nd Australian Division. The unity and links between the Allies were underlined further when, at 5 p.m., Admiral Didelot, the French governor of Le Havre, distributed prizes to the winning competitors. $7^{\circ}$ The festivities continued on the second and third days when all members of the military were admitted for free. A French national holiday for the l'Assomption de Marie fell on ${ }_{15}$ August. This seems to have encouraged locals to visit and peruse the products being displayed. The Army Service Corps (ASC) Base Depot Band played a variety of marching, concert, and waltz pieces (both British and French). The next day, the Army Ordnance Depot Band played an equally eclectic selection of tunes. Both concerts were followed by the Allies' national anthems. $7^{1}$

The 1917 event 'succeeded beyond expectations' and 'would have done credit to any county show'. $7^{2}$ The base staff felt that they had succeeded in their dual goals of increasing the "cultivation [of land around Le Havre] by the men in their spare time' and encouraging 'friendly rivalry among the Units'.73 There were 'some 65 o entries' from British sources alone. The sheer number of prizes and categories are revealing of both the productivity of the allotments around Le Havre and the complexity of the BEF's base camp. The BEF's competition included twenty-three individual categories. Amongst the winners were artillery depots, ASC depots, both human and veterinary hospitals, convalescent depots, field bakeries, headquarters, infantry depots, messes, military prisons, remount depots, Royal Army Medical Corps camps, rest camps, workshops, and Young Men's Christian Association (YMCA) huts. Cinder City, a sprawling encampment with a variety of institutions, competed individually, winning the peas category and being highly commended for their collection of vegetables and potatoes. 74

The Belgian military and French civilian classes were also 'well supported and created much interest'. It remains unclear why, but the 'French Military were not allowed to compete'. 75 There were eighteen winners - either prizes or commendations - across the six French categories. The medals and commendations

\footnotetext{
68 BL Tab. 1174 8.aa.4.96.

69 BL Tab. 1 748.aa.4.94.

$7^{\circ}$ BL Tab. 11748 .aa.4.103.

${ }^{71}$ BL Tab.11748.aa.4.102.

$7^{2}$ BL Tab. 1 748.aa.4.98.

73 Ibid.

74 BL Tab.11748.aa.4.115.

75 BL Tab. 11748 .aa.4.98.
} 
were awarded to a range of private citizens, institutions, and schools. The five Belgian military categories were specifically for artillery, auxiliary services, soldiers' homes, and camps for injured servicemen. ${ }^{6}$ The base commandant was gratified 'at the excellence of the exhibits' and the 'large...attendance of all ranks on each day'.77 Some 9,ooo people visited the show despite 'deplorable weather' and the 'inhabitants of Havre were much impressed with the utility and interest of the Show'. $7^{8}$ Yet, this was not simply a pleasant diversion, it had also contributed to the wider war effort. Over ' 3 ooo francs was received from "Gate" money', which was divided up and donated to French and British War Funds. The 'expenses were defrayed from subscriptions received from Officers stationed in Havre'.79 If any men were feeling guilty that others were fighting and dying around Ypres - or elsewhere in the world - then this was also an opportunity to feel that they had taken part in something contributing to the wider war effort. ${ }^{80}$

The governor of Le Havre was so impressed that he recommended that locals organize 'a show as an annual feature'. ${ }^{81}$ The British had, it seems, cemented themselves as part of the city's social and cultural life. It was agreed the competition would be repeated the following year, but this time it would be an even grander affair. The accounts for the 1918 event-unavailable for 1917 -show that the combined costs incurred amounted to nearly 3,500 francs with $3,05^{2}$ francs being spent on the goldsmiths' and silversmiths' medals alone. ${ }^{82}$ The planning began in May 1918 when new members of the organization committee were elected. They wanted to extend the competition's scope and considered including animals, namely poultry and rabbits. ${ }^{83}$ By this stage, men's protein allowance had been reduced so it seems unsurprising that there was a desire to now encourage husbandry alongside gardening. ${ }^{8}$ It was agreed that two birds, of any breed, could be presented 'killed and plucked'. Rabbits were to be presented alive, as pairs, in clean hutches. As well as the continued focus on quantity and size of vegetables, flowers were to be included. However, this class was restricted to women 'working with one of the recognised institutions'. ${ }^{5}$

The work of this committee was rather democratic. At times, it seems to have been an exercise in consensus building. When it came to decisions regarding new categories and how, for instance, the rabbits should be presented

$7^{6}$ BL Tab.1 174 8.aa.4.115.

77 BL Tab. 11748 aa.4.95.

$7^{8}$ BL Tab. 11748 .aa.4.98.

79 BL Tab. 1 748.aa.4.109.

8 o BL Tab. 11748 aa.4.95.

81 Ibid.

82 BL Tab.1 1 748.aa.4.106.

83 BL Tab.1 1748 .aa.4.107.

84 Beckett, Bowman, and Connelly, The British Army and the First World War, p. 15 o.

${ }_{5}$ BL Tab.1 1748 .aa.4.110. 
Table 1 Membership of the I9I 8 Vegetable Show Organization Committee

\begin{tabular}{ll}
\hline \hline Unit & \multicolumn{1}{c}{ Representative } \\
\hline Royal Garrison Artillery Base Depot & Lt. Col. C. W. Richardson \\
Guards Division Base Depot & Lt. Col. A. H. Royds \\
Headquarters, No. 1 Base & Maj. P. H. Browne \\
No. 1 Base Supply Depot & Maj. E. H. Cox \\
No. 1 Rest Camp & Maj. W. H. Finch \\
Army Service Corps Base Depot & Capt. H. W. E. Bainton MC \\
No. 2 Base Remount Depot & Lieut. H. Knothe \\
Area Agricultural Officer & Lieut. T. W. Powell \\
Australian Infantry Base Depot & Lieut. H. H. White \\
Australian General Base Depot & Lieut. C. L. Nelson \\
No. 4 Convalescent Depot & Gunner F. Gregory \\
No. 4 Convalescent Depot & Private Smith \\
No. 1 Emp. Base Depot & Capt. R. P. Thomson \\
Local Supplies & Capt. E. H. Barry \\
1 1 th Labour Group & Capt. W. Allan \\
14th Labour Group & 2nd Lieut. H. F. Poole \\
Chief Ordinance Officer & Sub. Con. Sully \\
No. 3 Military Prison & Sgt Wilkinson \\
Royal Garrison Artillery Base Depot & Sgt A. W. Fright \\
No. 1 Med. Bde. Base Depot & Cpl W. Bothwell \\
Deputy Assistant Director Railway Traffic & Cpl J. W. Burchett \\
Guards Division Base Depot & Private D. Campbell \\
No. 1 Rest Camp 'B' & Gunner E. Viggers \\
Prisoners of War Section, GHQ & Lieut. H. N. Miller \\
Army Printing \& Stationery Service & Lithographic Artist \\
\hline \hline
\end{tabular}

('trussed...[or] killed cleaned but in their skins'), committee members were tasked with obtaining the opinions of their units and neighbours. ${ }^{86}$ The committee itself was made up of men of almost every rank from lieutenant colonel to gunner. Table 1 highlights not only this, but also the range of activities and units based at Le Havre by May 1918 .

POW contingents, guardsmen, Australia and New Zealand Army Corps (ANZAC) troops, auxiliary services, cavalry, artillery, infantry, and the Labour Corps all took part; rarely would one have found an event that involved so many of the BEF's constituent parts. It is a vivid example of the complexity of military organizations by the end of the war and of an army international in character: there were Dominion units, other examples of the imperial war

${ }^{86}$ BL Tab. $11748 . a a \cdot 4 \cdot 107$. 
effort, and the Chinese Labour Corps. Records also indicate that Americans, Italians, Russians, and other nationalities were transiting through the port on a regular basis. ${ }^{8} 7$ It seems likely that the vegetable shows would have drawn a varied and cosmopolitan crowd.

The winners list for 1918 reveals the degree to which the competition had expanded. There were some 830 British entries (up nearly 200 from 1917) and, apparently, there was greater interest in the 'French Civilian' and 'Belgian Military' categories. Once again, the French military were, for some unknown reason, not allowed to compete. ${ }^{88}$ The standard of entries was apparently 'considerably higher than on the previous occasion' ${ }^{89}$ In the end, there were only two categories in the French competition. Five citizens shared the first, second, and third prizes and another eight were commended. The 'Jardins potagers de militaires Belges' saw individual (rather than unit) winners. $9^{\circ}$ In contrast, the 'Jardins potagers de troupes Belge' were shared by units: the Belgian artillery establishment at Gainneville took first prize, a Belgian Soldiers' Home came second, another artillery group third, and the 'Invalides Belges' were highly commended. The vegetable collection category was shared by units and installations from St Adresse, Gainville, and Sanvic.

Again, the BEF's winners reflect the variety of units that came under the command of the commandant at Le Havre. The Guards Division's Base Depot won three categories, as did No. 1 Rest Camp 'B'. No. 3 Military Prison took two awards. The 'B' Infantry Base Depot Supplies, 'Harfleur Gare'; Royal Garrison Artillery Base Depot; Army Service Corps Base Depot (HT\&S); 'A' Inf. Base Depot; and No. 1 Rest Camp 'A' were all awarded one gold medal apiece. $9^{1}$ Given the Guards' penchant for excellence, it comes as no surprise that they would have strived to be the best even here. $9^{2}$ Yet, for the rest camps and auxiliary units, this was the opportunity to develop some corporate pride, which it seems they did. The successes of the Depot Company of German POWs and the POW Convalescent Depot, who won second-place medals, might suggest that their prisoners offered little trouble, either

87 TNA WO 95/4031/6/1: war diary of base commandant Le Havre, 11-13 Aug. 1918, and TNA WO $0_{5} / 4^{0} 3_{1 / 6 / 2}$ : war diary of base commandant Le Havre, 14-16 Aug. 1918.

88 BL Tab. 11 748.aa.4.1 14. For the French Army, E. Greenhalgh, The French Army and the First World War (Cambridge, 2014); L. V. Smith, Between mutiny and obedience: the case of the French fifth infantry division during World War I (Princeton, NJ, 2016; orig. edn 1994); S. Audoin-Rouzeau, Men at war I91 4-I9I 8: national sentiment and trench journalism in France during the First World War, trans. H. McPhail (Oxford, 1995; orig. edn 1992).

89 BL Tab. 11748 .aa.4.114.

$9^{\circ}$ M. Amara, Des Belges à l'épreuve de l'exil: les réfugiés de la première guerre mondiale: France, Grande-Bretagne, Pays-Bas, I9I4-I9I8 (Brussels, 2008).

$9^{1}$ BL Tab.1 1748 .aa.4.108.

$9^{2}$ The regiments of the Foot Guards were at the top of the British Army's order of precedence and considered 'elite' in social as well as professional terms. D. French, Military identities: the regimental system, the British Army and the British people (Oxford, 2005), pp. 91-2, 165; E. M. Spiers, 'The regular army', in I. F. W Beckett and K. Simpson, eds., A nation in arms: the British Army in the First World War (Barnsley, 2004; orig. edn 1985), p. 43. 
helping in the cultivation of the allotments or allowing the guards to concentrate on these more peaceful pursuits. Furthermore, that depots and rest camps were able to win some plaudits, despite the men constantly filtering in and out of these establishments, also hints at a shared love of gardening that, perhaps, incentivized new men to carry on where others had left off.93

The organizing committee felt that the 1918 show was a triumph-greater, even, than the previous year. The yields from unit gardens had increased, while the base's relationship with the local populace was bolstered. P. H. Browne, now a major, argued that the show had succeeded in encouraging the cultivation of the fallow land around the camps and base. He reported that 'the very high cultivation and the excellent returns on all these gardens indicate that in friendly rivalry and undoubted keenness among all ranks stimulated their efforts with unexpectedly good results'. Certainly, a large quantity of vegetables were produced by No. 1 Base Camp, Le Havre, in the seven months prior to 31 December 1918 . Over $4,207,34^{1} \mathrm{lbs}$. of produce was grown in a cultivated area of 182.5 acres. Almost every unit in the region seems to have had allotments, though they varied in size and productivity. These included Chinese Labour Corps companies, 'Native' Labour Contingent camps, hospitals, Royal Engineer units, base depots, rest camps, and a variety of prisoner of war establishments. At Le Havre, it was a BEF-wide phenomenon. The Area Farm at Caueriauville had the highest yields and the biggest acreage. It was not, though, the most productive unit in relative terms-harvesting 11 lbs. $16.05 \mathrm{oz}$. of produce per acre. In contrast, the six most productive units outshone this specialist organization. Amongst these were No. 1 Rest Camp Section 'B' and No. 2 Veterinary Hospital. Yet, by far and away the most productive units were both POW contingents. The Depot Company of German POWs achieved a yield of 26 lbs. 14.5 oz. per acre and the Convalescent Depot of German POWs produced $20 \mathrm{lbs} .17 .5 \mathrm{Oz}$. of vegetables per acre. This was double the average for Le Havre as a whole. Whether these prisoners were forced to work - as they were in other circumstances - is unclear.94 It seems, though, that something was underpinning their levels of productivity, which the quality of soil alone could not explain.

It was not only the quantity and quality of the produce on show that reflected its success. 'About 11 , ooo people visited the show' over the course of the competition. Soldiers and locals flocked to the Jardin St Roche. The receipts show that $75^{2}$ francs were taken on the first day, 2,015 francs and 95 cents on 15 August (suggesting that the national holiday did encourage locals to attend), and a further $55^{8}$ francs and 25 cents on the final day. A further 304 francs and 40 cents was generated through programme sales with the YMCA tents

93 BL Tab.1 1748 .aa.4.113.

94 POWs did form labour companies elsewhere on the western front. H. Jones, Violence against prisoners of war in the First World War: Britain, France, and Germany, I9I4-I920 (Cambridge, 2011). 
contributing another 308 francs and 75 cents. Yet, to ensure that the show did not work to a loss, this income was boosted by 'subscriptions from Officers' that covered 'all [other] expenses'. These subscriptions amounted to 4,oog francs and 90 cents. This might be seen as a vivid example of the paternalistic duties of officers outlined by Gary Sheffield. 95 Their donations meant that the organizing committee was able to give 2,00o francs to the British Red Cross and a further 2,000 to the French Red Cross. In a numerical representation of the power of the different Allies, a smaller sum of 454 francs was donated to the Belgian Red Cross. A further pot of $16_{5}$ francs was set aside as tips for the staff at the show. $9^{6}$

\section{I I}

The scale of these shows is revealed in the documents collected by the staff at Le Havre. However, the thoughts and feelings of those soldiers taking part are harder to trace; at least until further material becomes available. 97 The British Museum's interest in the competition suggests that it may have been the largest organized on the western front. Yet, a similar initiative was proposed in the camps around Boulogne in the summer of 1918 , though it is unclear if it ever took place $.9^{8}$ Evidence of comparable activities can be found in the trench journal The Spud, later rechristened Sport $\mathcal{E} \mathcal{O}$ Spuds, a free periodical published by a physical and bayonet training school, somewhere close to Étaples.99 Here, like Le Havre, the camps were surrounded by a patchwork of 'Camp allotments'. Some members of the school apparently disliked gardening because, according to one article, such pursuits were 'too peaceful'. Yet, many other men devoted their 'spare time' to such activities before they were embraced by the military more officially. ${ }^{100}$ In March 1918, the school's allotments included multiple vegetable plots, fourteen pigs, six geese, seven ducks, thirtyfour hens, eighteen pigeons, and two bee colonies. ${ }^{101}$ The Spud and Sport $\mathcal{E}$ Spuds were published for the benefit of the 'Allotment Holders' around the base in the hope that the journal could offer advice on anything from rabbit rearing to marrow cultivation. ${ }^{102}$

\footnotetext{
95 Sheffield, Leadership in the trenches.

$9^{6}$ BL Tab.1 1748 .aa.4.106.
}

97 There is reference in the memoirs of Jessie Millar Wilson. J. E. Duncan, ed., Aunt J. Jessie Millar Wilson MBE: wartime memories of a lady YMCA volunteer in France, I9I 5-19I 8 (Ilkley, 1999), p. 49 .

$9^{8}$ 'Competitive cabbages', Sport E S Spuds, 3 ( 7 July 1918), p. 2.

99 Fuller, Troop morale, ch. 1; Audoin-Rouzeau, Men at war, ch. 1; R. L. Nelson, German soldier newspapers of the First World War (Cambridge, 2011 ), and 'Soldiers newspapers: a useful source in the social and cultural history of the First World War', War in History, 17 (2010), pp. 167-91; G. P. Seal, The soldiers' press: trench journals in the First World War (Basingstoke, 2013 ).

100 'An odds-on fight', Sport $\mathcal{E}$ Spuds, 2 (3o June 1918), p. 1.

101 'A modest beginning', The Spud, 1 (2 Mar. 1918), p. 1.

102 Ibid. 
These activities could encourage and cultivate morale-here defined as 'the process by which men, positively or negatively, rationalised their role as... members of the military'. ${ }^{103}$ This went beyond stress relief. The August 1918 edition of the journal highlighted the benefits of competitions. No. 12 Veterinary Hospital had put on a vegetable show. ${ }^{104} \mathrm{~A}$ staff officer, acting as judge, was apparently so impressed that he reported 'it was better than any Cottagers' flower-show he has seen'. Most important, though, was the emphasis on gaining 'credit for their unit'. ${ }^{105}$ The British Army's regimental system was one that encouraged corporate identity, even outside of traditional structures. ${ }^{106}$ The servicemen at No. 12 Veterinary Hospital seem to have embraced the contest. By competing against a neighbouring outfit, they were able to win some glory despite sitting very far away from the battle zone. It may also be that the use of allotments in this way brought men of rural and urban backgrounds together in a common endeavour.

The tending to these allotments and gardens also fed into men's reconceptualization of the western front. It nurtured a sense of ownership that was felt by the publishers of these journals when their camps were threatened by the German spring offensives in March 1918. The Sport $\mathcal{E}$ Spuds, published in August after the crisis had abated, explained that the German offensives were (at least in part) a symptom of their jealousy of the quality of the British gardens and allotments. ${ }^{107}$ While clearly making light of the war, this also hints at the ways in which men 'Tommified' the western front. ${ }^{108}$ The relief with which the editors noted that their gardens had so far been spared from the enemy seems authentic. The creation of these gardens, like the renaming of the landscape, allowed men to see Belgium and France as in some way British.

It also generated some agency within units at the blunt end of the war effort in a military that tended to stamp out individuality. While men complained about the rigours of training, which sparked a mutiny amongst troops at Étaples in 1917 , rear areas were generally a much safer and more pleasant place to be. ${ }^{109}$ Life in the camps was a world away from the firing line. For some men, their stint at a training camp was only a break from the pressures of frontline life, but for others this was their permanent posting. One poem in another issue of the journal highlighted many of the comparative benefits of life

103 A. Mayhew, 'Hoping for victorious peace: morale and the future on the western front', in L. Halewood, A. Luptak, and H. Smyth, eds., War time: First World War perspectives on temporality (Abingdon, 2019), p. 195.

104 'Play for your side', Sport E Spuds, 2oth Course (27 Aug. 1918), p. 1.

105 Ibid.

${ }^{106}$ French, Military identities. Also Bowman, Irish regiments in the Great War, pp. 10-31; Connelly, Steady the Buffs!, p. 7; A. Allport, Browned off and bloody-minded: the British soldier goes to war (New Haven, CT, 2015), pp. 22-5.

107 'The new rag', Sport E् Spuds, 1 (23 June 1918), p. 1.

108 R. J. Wilson, “Tommifying” the western front, 1914-1918', Journal of Historical Geography, 37 (2011), pp. 338-47.

${ }^{109}$ D. Gill and G. Dallas, 'Mutiny at Etaples Base in 1 91 7', Past $\mathcal{E}$ Present, 69 (1975), pp. 88-1 12. 
outside of combat units. It was generally 'quiet and peaceful and far from the guns' and thankfully one 'can't even smell the damn stink of dead Huns'. Importantly, men slept in beds and they were based right next to the sea. Unlike the almost exclusively masculine company kept in most units, there were also women in this sector: both members of the Women's Auxiliary Army Corps and French civilians on whom they could practise their French. ${ }^{110}$ It is unsurprising, then, that infantrymen were often embittered by the relative benefits enjoyed by units such as these. In both 1917 and 1918 , the Le Havre shows took place whilst fierce fighting continued in the forward zone. In August 1917, the British Army was struggling at Third Ypres, while a year later the second battle of the Marne (15 July to 6 August) and the battle of Amiens ( 8 through 11 August) had seen the Allies finally begin to beat back the Germans after their advances in the spring. ${ }^{111}$ Those men fighting and dying were undoubtedly the combatants at the sharp end of the war and the staff at these training depots were aware of this.

However, the military had become a lumbering goliath with a huge array of support troops that had to cope with and endure the war in different ways. The majority of men taking part in the No. 12 Veterinary Hospital's show were, apparently, 'old fellows of "crocks", $\mathrm{B}_{3}$ and $\mathrm{C}_{3}$ men'. ${ }^{12}$ This, a reference to official medical categories, indicates that the men involved had been classified as fit only for sedentary work. In this case, it was nursing the military's animals and, indirectly, helping the nation's food supply. When discussing their duties as physical trainers, one of the journal's authors pointed to their role in instilling 'the spirt of fight, / That was ever a Britisher's pride' in those passing through their classes. ${ }^{113}$ They were not unaware of the sacrifices of their comrades at the front. The 'white wooden boxes' stacked outside nearby hospitals were a reminder of the cost of the war. ${ }^{14}$ They were, though, keen to show they were 'doing their bit' and celebrated their contribution to the war effort. Working on allotments was a part of their sacrifice, which was relative; not everyone, thankfully for them, was able to risk their lives.

Perceptions of 'economies of sacrifice' were contingent on men's role and job. ${ }^{15}$ Interestingly, because of this, these soldiers were more willing to look positively on the contributions of those working in factories on the home

110 'Letters from Sergt. O’Grady at P. \& B.T. School to his sweetheart Mary', Sport EF Spuds, 2 (3o June 1918), p. 1.

${ }_{11}$ For the Passchendaele campaign, N. Lloyd, Passchendaele: a new history (London, 2017). For an international history of 1917 , D. Stevenson, I917: war, peace and revolution (Oxford, 2017). For the campaign coinciding with the 1918 show, J. Boff, Winning and losing on the western front: the British Third Army and the defeat of Germany in I9I8 (Cambridge, 2012). Also N. Lloyd, Hundred days: the end of the Great War (London, 2014). For 1918 as a whole,

D. Stevenson, With our backs to the wall: victory and defeat in I9I8 (London, 2012).

112 'A modest beginning', The Spud, 1 ( 2 Mar. 1918), p. 1.

113 'Bayonet's farewell to P. \& R.T.', Sport E Spuds, 19 th Course (3o July 1918), p. 4 .

114 'O'Grady's banquet', Sport $\mathcal{F}^{\circ}$ Spuds, 2oth Course (27 Aug. 1918), p. 4.

115 Gregory, The last Great War, ch. 4. 
front than were those serving in the frontlines. ${ }^{116}$ Those servicemen working in base camps, particularly in jobs linked to farming, had readier access to fresh (and high-quality) food than either combat troops or those in the United Kingdom. ${ }^{117}$ Their lives, as one poem highlighted, also held diversions not readily available to men in the line: lovely coastal scenes, a proximity to the 'homeland' (though this could be painful), shows, 'laughter and light', 'frolic and song', and 'girl things from Blighty'. ${ }^{118}$ This sense of relative privilege extended to those in Britain, where food shortages had started to bite in 1917; these men were better provisioned and catered for. ${ }^{119}$ Dwelling upon this, one author noted that 'at home...there are thousands of fellows slaving in Munition factories, with none of the glory which khaki confers'. Such empathy is difficult to find in the letters and publications of infantry units, which were often bitter about perceived inequalities. Even though those serving in base camps were able to 'trot around the woods' and 'sit at one's ease at the Café de Paris', they were still able to 'pat ourselves on the back because we are out in France helping to win the war'. ${ }^{120}$ In this case, at least, justifying their contribution to the war effort did not mean being unaware that they were privileged.

Another feature of modern war, at least with regards to the morale of civilian soldiers, was the ability to learn new trades. The war was, for many combatants, an opportunity to gain new skills, which might improve their life chances. When men left the military at the end of the war, they did so with character references and evidence of their training. ${ }^{121}$ As the war progressed, soldiers became increasingly specialized. Changing tactics saw men adopting particular roles within their unit - for instance in communications, bombing, or sniping - and there was instruction that accompanied this. The men's notebooks from their time on courses highlights how many embraced this as an educational experience. ${ }^{122}$ Working in these gardens and allotments offered another chance to gain skills (or to practise pre-existing ones) albeit in a less formal and organized manner. The Spud contained advice for the amateur gardeners from experts. This included guidance on how best to care for one's spade (the best hint being to 'keep... [it] as clean as you keep your rifle'); 'to dig with either hand and foot' so 'you won't tire one set of muscles'; the differences between and benefits of 'digging', 'trenching', and 'double-trenching'; how to divide plots

${ }^{116}$ Englander, 'Soldiering and identity', p. 312.

117 'Births' and 'Deaths', The Spud, 1 (2 Mar. 1918), p. 1.

118 'Then he woke up', Sport $\mathcal{E}$ S Spuds, 2oth Course (27 Aug. 1918), pp. 1-2. Also 'Cinema potentialities' and 'Our W.A.A.Cs', Sport E' Spuds, 22nd Course (30 Oct. 1918), pp. 1-2.

119 Gregory, The last Great War, pp. 214-16.

120 'Play for your side', Sport \& S Spuds, 2oth Course (27 Aug. 1918), p. 1.

121 Mayhew, 'Making sense of the western front', p. 146.

${ }^{122}$ NAM 1996-10-32-1: papers of A. W. F. Fuller, notebook including notes on bomber training; NAM 1979-07-178: notebook of W. M. Spencer Edge; Liddle Collection, University of Leeds WW1/GS/o582: 2nd Lt. R. V. D. Francis, notebook esp. 'Notes-Sniping' and 'Notes-Gas Respirators'. 
longitudinally; and strategies for digging and cultivation of different seeds. ${ }^{123}$ Men could learn the necessary skills to maintain their own allotments and to provide for their families once they returned home.

The sense that these men were relatively privileged reveals a further layer of this story and helps to explain why the commandant at Le Havre was so keen to see the use of allotments expand. A great strain was placed on combatant societies in 1917 , which required the remobilization of allies and enemies alike. ${ }^{124}$ Local and national authorities in Britain also embraced allotments. Households had been encouraged to grow their own food from the early days of the war, but the German U-Boat campaign had made food supply an even more pressing concern by the spring and summer of 1917 . Model allotments were constructed across the country (including in Regent's Park and Kensington Gardens) and widespread 'allotmentitis' saw the number of plots in Britain swell from 44 o,ooo in 1914 to an estimated 1.5 million by $1918 .{ }^{125}$ While there is no evidence that military authorities in Le Havre were responding directly to this, they must have been aware of the phenomenon. The best food and supplies were reserved for fighting men, but the BEF was not immune to the problems facing civil society. Men's rations were affected by the disruption to food supply and were also prey to the military's attempts to cut costs. ${ }^{126}$ In 1917 and 1918 , the strains of war were - beyond casualty figures - being felt by the army and savings and efficiency gains were demanded of the BEF. Efforts were made to reduce its expenditure by, for instance, cutting the protein, bread, cheese, and even tea allowance of troops. ${ }^{127}$ It is unsurprising, then, that men saw these allotments as an opportunity to supplement their diet. The military saw this too, which prompted the base commandant at Le Havre to find ways to encourage the cultivation of the unused land between the myriad camps. Consequently, the vegetable show was conceived at least nominally 'with a view to showing his appreciation of the efforts now being made by practically every Unit in his Command, to cultivate all vacant land for the production of vegetables, and to encourage the continuity of this work'. ${ }^{128}$ The development and institutionalization of the allotments also seems to have produced an internal market of sorts. There were market rates for produce and a

123 'Hints on digging', The Spud, 1 (2 Mar. 1918), pp. 1-2.

124 J. Horne, 'Remobilising for "total war": France and Britain, 1917-1918', in J. Horne, ed., State, society and mobilization in Europe during the First World War (Cambridge, 1997), pp. 195-211. This fed into education programmes in the BEF, S. P. Mackenzie, 'Morale and the cause: the campaign to shape the outlook of soldiers in the British Expeditionary Force, 1914-1918', Canadian Journal of History/Annales Canadiennes d'Histoire, 25 (1990), pp. $215^{-} 3^{2}$.

125 See, for example, G. Butcher, Allotments for all: the story of a great movement (London, 1918), p. 24; S. Poole, The allotment chronicles: a social history of allotment gardening (Kettering, 2006).

${ }^{126}$ Duffet, The stomach for fighting, p. 124.

127 War Office, Statistics of the military effort of the British empire during the Great War (London, 1922 ), p. $5^{84}$.

${ }_{128}$ BL Tab. 11748 .aa.4.91. 
quasi 'sharing economy' in which tools, products, and seeds were exchanged. ${ }^{129}$ It seems significant that men, and then the army, turned to allotments, which had been celebrated as a tool for alleviating poverty and unemployment before the war. ${ }^{130}$ In an army predominantly composed of civilians, it was to the civilian world that they looked to when searching for solutions to military problems.

\section{V}

Focusing on particular events, particularly in the base camps, reveals the true complexity and diversity of soldiers' experiences during the First World War, while the British Army's organization can be seen with greater clarity. Many years ago now, Peter Simkins noted that historians 'are in broad agreement that the nature of British society in $1914^{-1} 8$ provided a bedrock of social cohesion which prevented the BEF from total collapse'. ${ }^{13^{1}}$ The events at Le Havre suggest that senior officers, at least in the staff at No. 1 Base Camp, were aware of this and that by 1917 they were actively mobilizing culture as a mechanism for their military ends: be it to foster corporate identity or to encourage the cultivation of land. Indeed, it has been suggested that it was this willingness to adopt civilian thought and behaviour that stood the British Army apart from many of its contemporaries. ${ }^{132}$ Not only this, but the particular example of vegetable shows in Le Havre tells us an immense amount about the percolation of popular culture deep into the fibres of the British military. So much so that as they sought to reduce costs and improve self-sufficiency, it was to the British love of gardening that the military authorities turned. Significantly, these were-like sports and theatre-activities that first started as pastimes pursued by soldiers when not on duty. It was the popularity and productivity of these allotments and gardens that convinced the army to adopt and institutionalize them. In this way, the BEF was an organization that (while heavily dependent on discipline) was willing and able to adopt ideas and strategies originating in the off-duty activities of its most lowly ranking members.

The vegetable shows also reveal the diversity of experiences found if one studies events away from the frontlines. Far from the popular myth of mud and blood, still so dominant outside of academic circles, life behind the lines could be diverting and enjoyable - a place to learn new trades, escape the war, and relax. What is more, these events would have never taken place were

129 'A modest beginning', The Spud, 1 ( 2 Mar. 1918), p. 1.

${ }^{130} \mathrm{~J}$. Buchardt, The allotment movement in Britain, I793-1873 (Woodbridge, 2002), and 'Land and labourer: potato grounds and allotments in nineteenth century southern England', Agricultural History, 74 (2000), pp. 667-84.

${ }^{131}$ P. Simkins, 'Everyman at war: recent interpretations of the front line experience', in B. Bond, ed., The First World War and British military history (Oxford, 1991), p. 301.

${ }^{132}$ Watson, Enduring the Great War, p. 4. Watson was reflecting on the conclusions of German historian Christoph Jahr. 
it not for the complex and positive relationship that developed between the British Army and the French civil population. Far from simply tolerating each other's presence, events such as this demonstrate how soldiers and civilians intermingled and, it seems, could enjoy their exposure to one another. Pandemic restrictions meant that-beyond a press clipping in the British Library's collection-it was not possible to access local newspapers in Le Havre to study French civilians' reactions to these events through anything but a British lens, which might be rectified in future analyses. It also remains to be seen why the French military were not allowed to take part: was there a more strained relationship between the British and French militaries or, indeed, did the French military look on such entertainment with disdain? While it is unlikely that scholars will unearth material that shatters historical understanding of $1914^{-18}$, documents related to events such of those that took place at Le Havre undoubtedly still sit in archives, both local and national, ready to deepen our understanding of the Great War. 